\title{
Palladium-catalyzed borylation and Suzuki coupling (BSC) to obtain $\beta$-substituted dehydroamino acid derivatives
}

\author{
Ana S. Abreu, Natália O. Silva, Paula M.T. Ferreira and \\ Maria-João R.P. Queiroz ${ }^{*}$
}

Departamento de Química, Universidade do Minho, Campus de Gualtar, 4710-057 Braga, Portugal

\begin{abstract}
Several benzo[b]thienyldehydroamino acids were prepared by one pot palladium-catalyzed borylation and Suzuki coupling (BSC) from bromobenzo[b]thiophenes containing EDG (OMe or $\mathrm{Me}$ ), as the component to be borylated with pinacolborane, and pure stereoisomers of $\beta$ bromodehydroamino acid derivatives. To our knowledge it is the first time that the BSC reaction involves a non aromatic system.
\end{abstract}

Keywords: benzo[b]thiophenes; borylation; palladium; Suzuki coupling; dehydroamino acids.

\section{Introduction}

In the last few years we have been interested in the synthesis of non-proteinogenic amino acids, ${ }^{1}$ in particular in the preparation of benzo[b]thienyldehydroamino acids for biological and/or photochemical applications. ${ }^{2}$

Recently we have described the successful application of the BSC reaction ${ }^{3}$ to the synthesis of 2-methyl-2'-nitro diaryl compounds in the benzo[b]thiophene series. ${ }^{4}$ Here we describe the use of the same methodology to synthesize benzo[b]thienyldehydroamino acids from ortho-methylated or methoxylated bromobenzo[b]thiophenes, as the component to be borylated, and pure stereoisomers of $\beta$-bromodehydroamino acid derivatives. To our knowledge it is the first time that this BSC reaction involves a non aromatic system.

\section{Results and discussion}

\footnotetext{
*Email: mjrpq@quimica.uminho.pt, Fax: +351-253678983
} 
The $\beta$-bromodehydroamino acid derivatives were prepared according to a procedure already described by us and when necessary the stereoisomers were separated by column chromatography. ${ }^{2 a}$ The bromobenzo[b]thiophenes were obtained by bromination (using $\mathrm{Br}_{2}$ ) of the corresponding methylated ${ }^{5}$ or methoxylated $^{6}$ benzo[b]thiophenes. These were used as the component to be borylated with pinacolborane and the other Suzuki component was a $\beta$-bromodehydroamino acid derivative (Scheme 1).

The benzo[b]thienyldehydroamino acid derivatives 1-5 were obtained in moderate to good yields (Table 1), with maintenance of the stereochemistry, which was determined by NOE difference experiments. In all cases debrominated methoxy or methylbenzo[b]thiophenes were isolated as by-products in $25-35 \%$ yield. When $\beta$-bromodehydroalanine was used, addition of water in the Suzuki coupling gave the products in lower yields. In fact compound $\mathbf{1}$ was obtained only in $22 \%$ yield when water was added in the second step and in $44 \%$ yield without water. With the other dehydroamino acid derivatives the addition of a small amount of water increased the product yields. For instance, the yield in the synthesis of compound $\mathbf{3}$ was increased from $40 \%$ to $61 \%$ (see ref. 7 ).

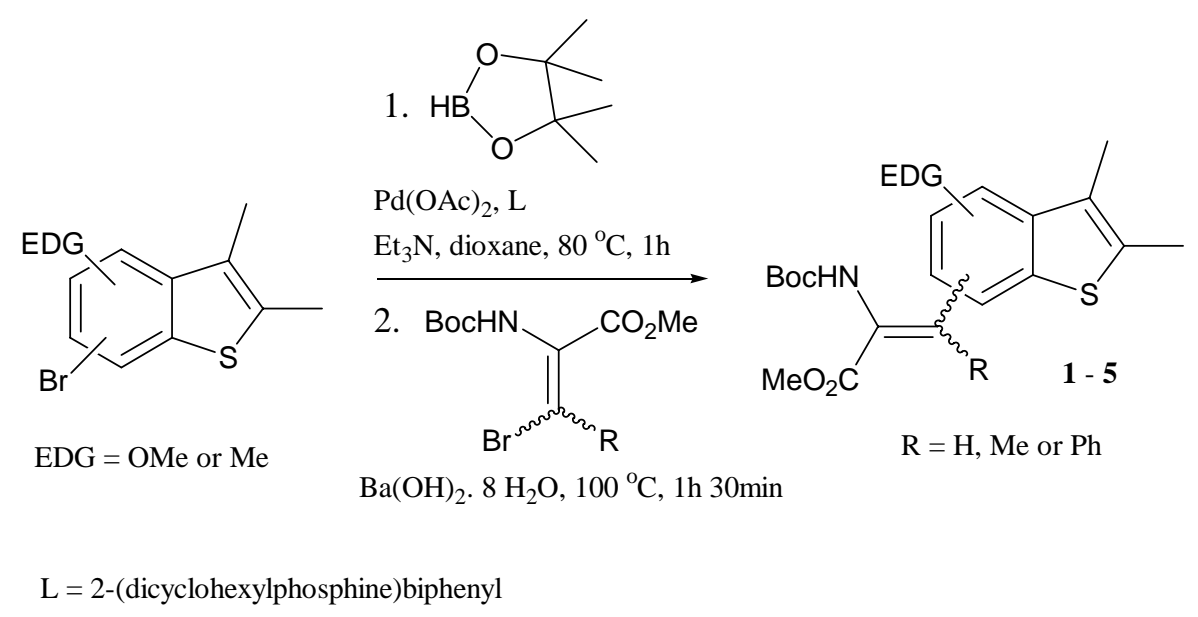

Scheme 1.

As postulated by others for aromatic systems ${ }^{3}$ the component to be borylated needs an EDG and the Suzuki coupling component requires an EWG. In our case experiments using bromobenzo[b]thiophenes without an EDG were unsuccessful confirming the importance of the presence of such a group. The dehydroaminoacid derivative acts as the coupling component having an EWG. However the carbamate group has a slight electron donating effect which can have some influence in the product yields. 


\section{Conclusion}

With these results the scope of the BSC reaction was extended to non aromatic Suzuki coupling components. Despite the moderate to good yields obtained, this reaction allows the palladium catalyzed borylation and Suzuki coupling in a one pot procedure avoiding the lithiation step and transmetalation to boron.

The benzo[b]thienyldehydroamino acids obtained are non-proteinogenic amino acids that can be used either as conformational constrains when inserted into peptides or in the development of peptidomimetics. They can also have biological activity as sulfur analogues of dehydrotryptophan.

Table 1. Brominated starting materials and product yields of the BSC reaction.

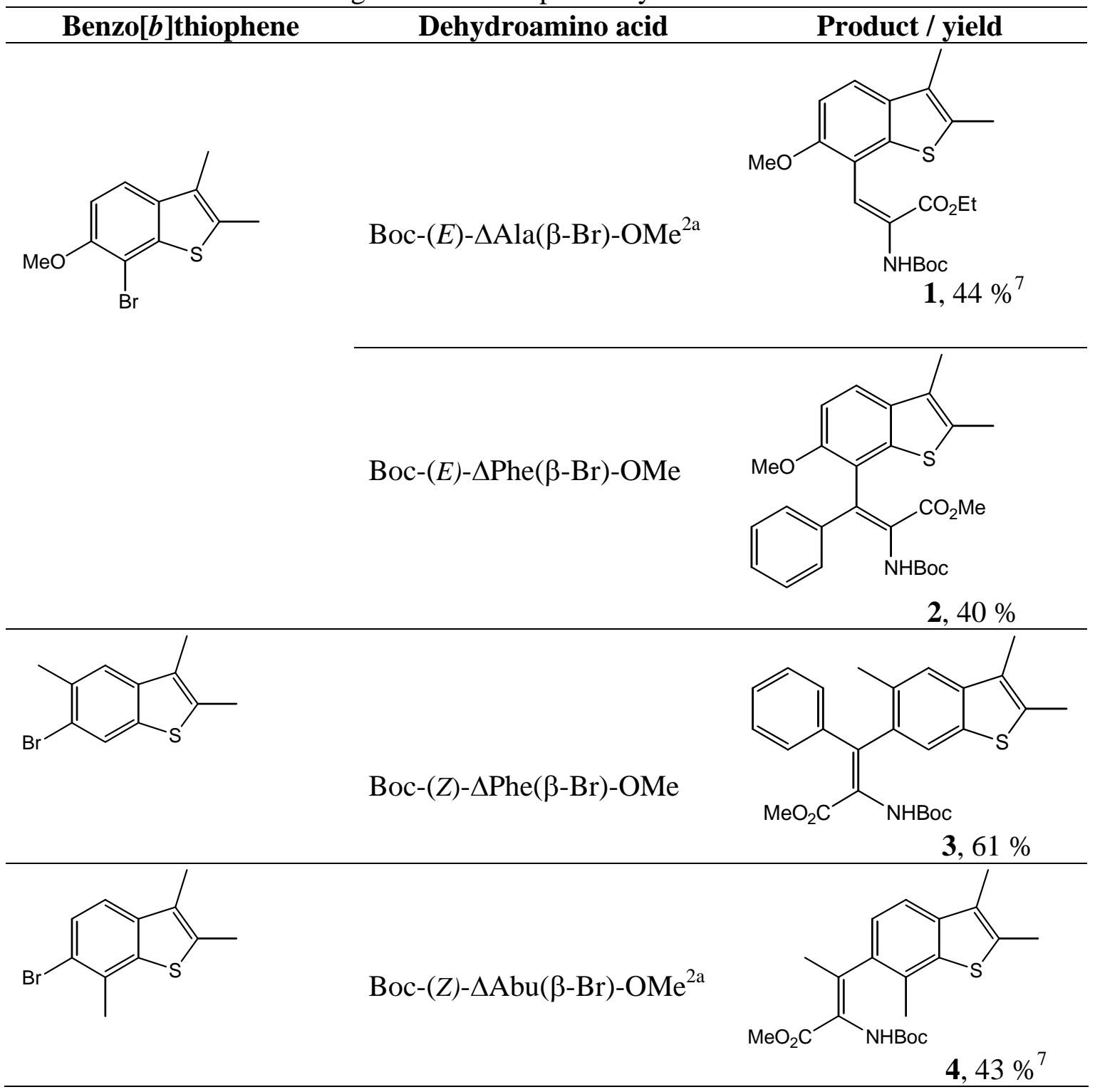




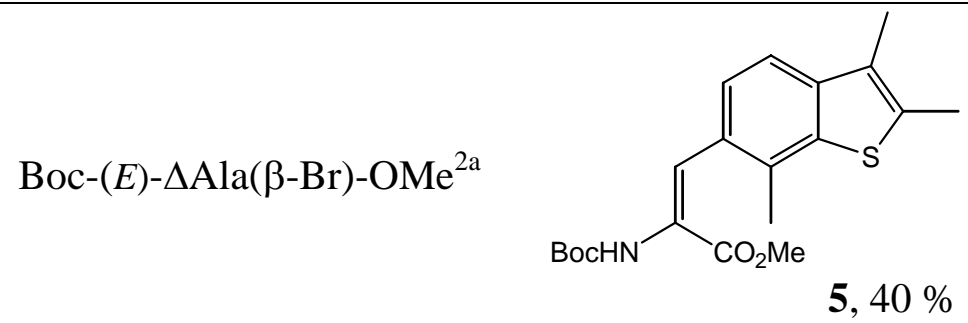

\section{Acknowledgements}

We thank the Foundation for Science and Technology (Portugal) for financial support through IBQF-Univ. Minho, project POCTI/1999/QUI/32689 and through SFRH/BD/4709/2001, PhD financial support of A.S. Abreu.

\section{References}

1. (a) Ferreira, P.M.T., Maia, H., Monteiro, L.S., Sacramento J. and Sebastião, J. J. Chem. Soc. Perkin Trans. 1, 2000, 3317-3324. (b) Ferreira, P.M.T., Maia, H., Monteiro, L.S. and Sacramento, J. J. Chem. Soc. Perkin Trans. 1, 2001, 3167-3172.

2. (a) Silva, N. O.; Abreu, A. S.; Ferreira, P. M. T.; Monteiro L.M.S. and Queiroz, M.-J. R. P. Eur. J. Org. Chem., 2002, 2524-2528. (b) Abreu, A. S.; Silva, N. O.; Ferreira, P. M. T. and Queiroz, M.-J. R. P. Eur. J. Org. Chem., 2003, 1537-1544.

3. (a) Baudoin, O.; Guénard, D. and Guéritte, F. J. Org. Chem., 2000, 65, 9268-9271. (b) Baudoin, O.; Cesario, M.; Guénard, D. and Guéritte, F. J. Org. Chem., 2002, 67, 1199-1207.

4. Ferreira, I.C.F.R.; Queiroz, M.-J. R. P. and Kirsch, G. Tetrahedron Lett., 2003, 44, 4327-4329.

5. Ferreira, I.C.F.R.; Queiroz, M.-J. R. P. and Kirsch, G. J. Het. Chem., 2001, 38, 749-754.

6. Queiroz, M.-J. R. P.; Dubest, R.; Aubard, J.; Faure, R.; Guglielmetti, R. Dyes and Pigments, 2000, 47, 219-229.

7. Boc-(E)- $\Delta$ Ala-[ $\beta$-(2,3-dimethyl-6-methoxybenzo[b]thien-7-yl)]-OMe (1): A dry Schlenck tube was charged under Ar with 7-bromo-2,3-dimethyl-6-methoxybenzo[b]thiophene (0.5 mmol) in dioxane (2 $\mathrm{mL}$ ), $\mathrm{Et}_{3} \mathrm{~N}$ (4 equiv.), $\mathrm{Pd}(\mathrm{OAc})_{2}$ (5 mol\%), 2-(dicyclohexylphosphino)biphenyl (20 mol\%) and pinacolborane (3 equiv.) and the mixture was heated at $80{ }^{\circ} \mathrm{C}$ for $1 \mathrm{~h}$. After cooling Boc- $(E)-\Delta \mathrm{Ala}(\beta-\mathrm{Br})-$ OMe (1 equiv.) and $\mathrm{Ba}(\mathrm{OH})_{2} \cdot 8 \mathrm{H}_{2} \mathrm{O}$ (3 equiv.) were added, and the solution was heated at $100{ }^{\circ} \mathrm{C}$ for $1 \mathrm{~h}$ $30 \mathrm{~min}$. After cooling, water and ethyl acetate were added. The phases were separated, the aqueous phase was extracted with more ethyl acetate and the organic phase was dried $\left(\mathrm{MgSO}_{4}\right)$ and filtered. Removal of the solvent gave a brown solid which was submitted to column chromatography using solvent gradient from neat petroleum ether $40-60{ }^{\circ} \mathrm{C}$ to $30 \%$ ether/ petroleum ether $40-60{ }^{\circ} \mathrm{C}$ to give the product as a beije solid (86 mg, $44 \%$ ) which was recrystallized from ether/petroleum ether $40-60{ }^{\circ} \mathrm{C}$ to give colourless crystals m.p. $132.5-133{ }^{\circ} \mathrm{C}$; found C, 61.34; H, 6.53; N, 3.55; S, 8.22\%, calcd for $\mathrm{C}_{20} \mathrm{H}_{25} \mathrm{NO}_{5} \mathrm{~S}$ C, 61.36; H, 6.44; N, 3.58; S, 8.19\%; $\delta_{\mathrm{H}}\left(300 \mathrm{MHz}, \mathrm{CDCl}_{3}\right) 1.36$ (s, 9H, $\left.\mathrm{CH}_{3} \mathrm{Boc}\right), 2.27$ (s, 3H, $\left.\mathrm{ArCH}_{3}\right), 2.45$ (s, 3H, 
$\mathrm{ArCH}_{3}$ ), 3.90 (s, 3H, OCH ${ }_{3}$ ), 3.96 (s, 3H, OCH 3 ), 6.76 (s, 1H, NH), 7.06 (d, 1H, ArH, J $\left.8.7 \mathrm{~Hz}\right), 7.08$ (s, $1 \mathrm{H}, \beta \mathrm{CH}) 7.54$ (d, $1 \mathrm{H}, \mathrm{ArH}, J 8.7 \mathrm{~Hz}) ; \delta_{\mathrm{C}}\left(75.4 \mathrm{MHz}, \mathrm{CDCl}_{3}\right) 11.38\left(\mathrm{CH}_{3}\right), 13.65\left(\mathrm{CH}_{3}\right), 28.00\left(\mathrm{CH}_{3} \mathrm{Boc}\right)$, $52.50\left(\mathrm{OCH}_{3}\right), 56.89\left(\mathrm{OCH}_{3}\right), 80.57(\mathrm{C}) 109.54(\mathrm{CH}), 116.39(\mathrm{C}), 119.29(\mathrm{CH}), 122.09(\mathrm{CH}), 126.58(\mathrm{C})$, 128.46 (C), 132.26 (C), 135.56 (C), 139.03 (C), 152.49 (C), 153.57 (C=O), 165.62 (C=O).

Boc-(Z)- $\Delta$ Abu-[ $\beta-(2,3,7-t r i m e t h y l b e n z o[b]$ thien-6-yl)]-OMe (4): Following the same procedure described above with 6-bromo-2,3,7-trimethylbenzo[b]thiophene ( $0.5 \mathrm{mmol}$ ) but adding water (200 $\mu \mathrm{L})$ and Boc- $(Z)-\triangle \mathrm{Abu}(\beta-\mathrm{Br})-\mathrm{OMe}$ in the second step, the product was isolated as a white solid, after column chromatography (84 mg, 43\%) and was recrystallized from petroleum ether $40-60{ }^{\circ} \mathrm{C}$ to give colourless crystals m.p. 87-88 ${ }^{\circ} \mathrm{C}$; found C, 64.69; H, 7.03; N, 3.53; S, 8.23\%, calcd for $\mathrm{C}_{21} \mathrm{H}_{27} \mathrm{NO}_{4} \mathrm{~S}$ C, 64.76; $\mathrm{H}$, 6.99; N, 3.60; S, 8.23\%; $\delta_{\mathrm{H}}\left(300 \mathrm{MHz}, \mathrm{CDCl}_{3}\right) 1.38$ (s, 9H, $\left.\mathrm{CH}_{3} \mathrm{Boc}\right), 2.20$ (s, 3H, $\mathrm{CH}_{3}$ ), 2.31 (s, 3H, $\mathrm{ArCH}_{3}$ ), 2.38 (s, 3H, $\mathrm{ArCH}_{3}$ ), 2.52 (s, 3H, $\mathrm{ArCH}_{3}$ ), 3.88 (s, 3H, $\mathrm{OCH}_{3}$ ), 5.53 (s, 1H, NH), 7.07 (broad d, $1 \mathrm{H}, \mathrm{ArH}, J 8 \mathrm{~Hz}), 7.49(\mathrm{~d}, 1 \mathrm{H}, \mathrm{ArH}, J 8 \mathrm{~Hz}) ; \delta_{\mathrm{C}}\left(75.4 \mathrm{MHz}, \mathrm{CDCl}_{3}\right) 11.40\left(\mathrm{CH}_{3}\right), 13.78\left(\mathrm{CH}_{3}\right), 17.05$ $\left(\mathrm{CH}_{3}\right), 20.80\left(\mathrm{CH}_{3}\right), 28.00\left(\mathrm{CH}_{3} \mathrm{Boc}\right), 51.94\left(\mathrm{OCH}_{3}\right), 80.66(\mathrm{C}) 119.51(\mathrm{CH}), 123.77(\mathrm{CH}), 125.15(\mathrm{C})$, 127.17 (C), 128.09 (C), 132.22 (C), 133.53 (C), 134.22 (C), 139.28 (C), 140.27 (C), 152.91 (C=O), $155.57(\mathrm{C}=\mathrm{O})$. 